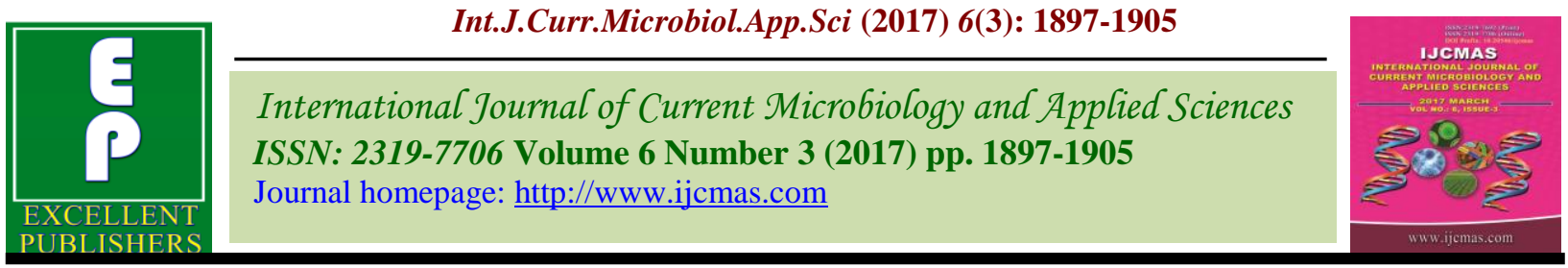

\title{
Effect of Sunlight and UV Light against DpNPV (Nuclear Polyhedrosis Virus) Formulation on Larval Mortality of Mulberry Leaf Webber, Diaphania pulverulentalis Hampson
}

\author{
S. Prabhu ${ }^{1}$ and C.A. Mahalingam ${ }^{2}$ \\ ${ }^{1}$ Department of Agricultural Entomology, RVS Padmavathy College of Horticulture \\ (Affiliated to Tamil Nadu Agricultural University, Coimbatore), Sempatti- 624 707, India \\ ${ }^{2}$ Department of Agricultural Entomology, Tamil Nadu Agricultural University, \\ Coimbatore- 641 003, India \\ *Corresponding author
}

\section{A B S T R A C T}

\begin{tabular}{|l|}
\hline Ke y w o r d s \\
Mulberry, \\
Diaphania \\
pulverulentalis, \\
NPV, Sunlight, \\
UV light.
\end{tabular}

Effect of sunlight and UV light on the inactivation of nuclear polyhedrosis virus to Diaphania pulverulentalis (Hampson). Larvae were studied under laboratory conditions. The larval mortality was significantly maximum $(76.66 \%)$ and $(86.65 \%)$ when $D p N P V$ suspension and formulation was exposed to sunlight for 1 hour respectively. Minimum mortality of $(48.33 \%)$ and $(61.66 \%)$ of $D p N P V$ suspension and formulation were observed when it was exposed to sunlight for 5 hours which indicating reverse relationship between the exposure duration to sunlight and larval mortality. Inactivation of $D p N P V$ by UV light was demonstrated by the decreased mortality rate in larval groups inoculated with irradiated virus compared to those fed on non- radiated virus i,e., control. Significant difference in larval mortality was observed when $D p N P V$ was exposed to 5, 10, 15, 30 and 60 minutes to UV light, $(88.33,85.00,80.00,66.66$ and $53.33 \%$ mortality respectively). Whereas in formulated $D p \mathrm{NPV}$, the rate of larval mortality recorded was 93.33, 90.00, 86.65, 71.66 and 66.66 per cent when exposed to $5,10,15,30$ and 60 minutes to UV light respectively. The inactivation of virus was directly related to the period of exposure to UV radiation. This finding indicated a loss in pathogenicity and the number of days to death was higher and the total mortality was lower from exposed virus than from unexposed virus.

\section{Introduction}

The leaf webber Diaphania pulverulentalis (Hampson) (Lepidoptera : Pyralidae), is a key pest of mulberry in India. As recently become a major problem for mulberry cultivators in south India causing a leaf yield loss of 12.8 per cent with an average incidence of 21.77 per cent. In recent years, D. pulverulentalis, a new invader from Karnataka to Tamil Nadu is posing a serious threat to farmers (Geetha Bai et al., 1997).
Timely management of insect pests is essential to avoid economic loss to farmers. However, regular usage of toxic chemicals in mulberry garden to control the pests caused pollution and was detrimental to human beings and beneficial organisms including silkworms. Further, the pests developed resistance to the chemical insecticides with indiscriminate use and resulted in sudden outbreak. In view of these, pest management 
using non-chemical methods gained importance including biological control.

Among bio control agents, baculovirus are very important as they are arthropod specific pathogens. Higher host specificity and amenability for formulation as that of chemical pesticides make baculoviruses particularly attractive as biological control agents (Dent and Jenkins, 2000).

One of the most important naturally occurring pathogens of $D$. Pulverulentalis larvae is Nuclearpolyhedrosis virus (NPV), a baculovirus capable of causing epizootics in the larval population that result in declines or elimination of populations (Narayanaswamy et al., 2008).

One of the major drawbacks of using entomopathogens as biopesticides is their lack of persistence in the environment. Their infectivity is affected by environmental factors such as sunlight radiation, temperature, moisture and $\mathrm{pH}$. These factors limit the field application and subsequent commercialization of many entomopathogens, including baculoviruses (Rabindra and Jayaraj, 2005).

Priyadharshini, 2009 reported that, Baculoviruses, particularly, nucleopolyhedroviruses (NPV), are deleteriously affected by sunlight radiation. Shapiro et al., (2002) conducted bioassay to compare the biological activities of $\mathrm{HzSNPV}$ against Heliothis zea larvae and SeMNPV against Spodoptera exigua larvae with the virus concentrations ranging from $10^{1}\left(=0.0074 \mathrm{PIB} / \mathrm{mm}^{2}\right)$ to $10^{6}$ PIBs/cup $\left(=744.4 \mathrm{PIBs} / \mathrm{mm}^{2}\right)$ before and after irradiation. The UV-B/UV-A combination tubes were effective in inactivating both viruses and the effects were dependent upon both the length of UV exposure and the virus concentrations. Temperature also interacted with sunlight to alter its effect on viruses. McLeod et al., (1977) showed that $\mathrm{HzNPV}$ inactivation by UV lights increased significantly as the temperature increased from 15 to $45^{\circ} \mathrm{C}$.

Being obligate pathogens, viruses cannot multiply outside the environment of the host insect and have to remain in a viable state before they are ingested by the host insect. A number of materials tested for use as adjuvants to protect the baculoviruses from sunlight inactivation, Tinopal, sugars such as sucrose, fructose and sorbitol have been proved to increase the efficacy of NPV formulation (Sajap et al., 2009). Hence, the present study was to determine the effect of sunlight and UV light on the infectivity of both $D p N P V$ and its formulation to $D$. Pulverulentalis larvae.

\section{Materials and Methods}

\section{Effect of sunlight exposed $D p N P V$ and their formulation}

The persistence of $D p N P V$ was assessed by exposing the virus to sunlight for different periods. The viral suspension and $D p N P V$ formulation (Starch 10\%+ Tinopal 0.2\%+ Tween $80 \quad 1 \%+D p N P V)$ containing $1 \times 10^{9}$ $\mathrm{POB} / \mathrm{ml}$ was poured into petri plates and the polyhedra were exposed outdoors to direct sunlight in open dishes for 1, 2, 3, 4 and 5 hours. After exposure, the samples were resuspended in distilled water at the original concentration. Mulberry leaf discs were cut and treated with polyhedral bodies at the centre of the discs and spread uniformly using the polished blunt end of a sterile glass rod. After the suspension had dried off, the disc was turned over and the other surface was treated similarly. Larvae fed on leaf discs without virus treatment were also maintained as control $(0 \mathrm{~h})$. Twenty numbers of third instar larvae per replication were used in the assay and larvae were released individually. After consuming of whole discs, the larvae were transferred to fresh discs. Each treatment was replicated three times. The leaf discs 
were placed in containers lined with moist filter paper discs to maintain the freshness and moisture content of the discs, the larval mortality was recorded 4-10 days post inoculation (Sajap et al., 2007).

\section{Effect of UV light exposed $D p N P V$ and their formulation}

Laboratory assays were conducted to find out the UV stability of an in-vivo produced virus. Both virus suspension $\left(1 \times 10^{9}\right.$ POBs $)$ and formulation (Starch $10 \%+$ Tinopal $0.2 \%+$ Tween80 $1 \%+D p N P V)$ containing $1 \times 10^{9}$ $\mathrm{POB} / \mathrm{ml}$ were taken in open petri dishes $(60$ by $15 \mathrm{~mm}$ glass) placed $19.5 \mathrm{~cm}$ below the UV lamp. Wet virus was exposed for periods of 5, 10, 15, 30 and 60 minutes, respectively. After the exposure periods, the remaining volumes were determined and distilled water was added to each dish to replace water lost by evaporation. Lids were then placed on all dishes and were stored at $4^{0} \mathrm{C}$ until usage.

Leaf discs treated with $D p \mathrm{NPV}$ inoculum were spread uniformly on both sides of mulberry leaf discs by using blunt ended sterile glass rod. Twenty number of third instar larvae of leaf webber were used per replication. The control was also maintained by treating the leaf disc with unexposed $D p N P V$. Each treatment was replicated five times and the mortality was recorded at $4^{\text {th }}, 7^{\text {th }}$ and $10^{\text {th }}$ day (Bullock et al., 1970).

\section{Results and Discussion}

Effect of exposure duration of sunlight on $D p N P V$ and their formulation on the larval mortality of leaf webber, $D$. pulverulentalis

The present study is in conformity with Morris (1971) who reported that one hour and five hours exposure of NPV of western hemlock looper (Lambdina fuscellarialugubrosa) to sunlight caused mortality of 72.0 and 50.0 per cent respectively. The rate of larval mortality in $D$. pulverulentalis due to inoculation of $D p \mathrm{NPV}$ and their formulation differed significantly when exposed to different durations of sunlight. Among the exposure lots of $D p N P V$ suspension (Table 1) the larval mortality was significantly maximum (76.66 \%) when $D p \mathrm{NPV}$ was exposed to sunlight for $1 \mathrm{hr}$, which was followed by mortality of 68.33 , $68.33,53.33$ and 48.33 per cent for 2, 3, 4 and $5 \mathrm{hr}$ respectively.

The mortality caused by Malacosoma disstria NPV exposed to sunlight on the sweet gum foliage was 87.00 per cent at $0 \mathrm{~h}$ exposure (Broome et al., 1974), which was slightly high in the similar study with $(91.25 \%)$ at the $0 \mathrm{~h}$ exposure (Priyadharshini, 2009). Ignoffo et al., (1989) reported the effect on the inactivation of occluded baculoviruses. Whereas, with formulated $D p N P V$ (Starch 10\%+ Tinopal $0.2 \%+$ Tween $80(1 \%)+D p N P V @ 1 \times 10^{9}$ POBs $\mathrm{ml}^{-1}$ ) the larval mortality was significantly maximum $(86.65 \%)$ when exposed to sunlight for $1 \mathrm{hr}$, which was followed by mortality of $78.33,71.66,65.00$ and 61.66 per cent for 2, 3, 4 and $5 \mathrm{hr}$ respectively, indicating inverse relationship between the exposure duration to sunlight and larval mortality. However, the mortality rate of 90.00 and 93.33 per cent were recorded in unexposed $D p \mathrm{NPV}$ suspension and formulated $\quad D p \mathrm{NPV}$ (i,e., control) respectively. (Fig. 1) Hence, the larval mortality decreased with increase in exposure duration of sunlight. This indicated a loss in pathogenicity and the number of days to death was higher and the total mortality was lower from exposed virus than from unexposed virus. 
Table.1 Effect of sunlight exposed DpNPV suspension and its formulation against larvae of $D$. pulverulentalis

\begin{tabular}{|c|c|c|c|}
\hline \multirow{2}{*}{ S.No } & \multirow{2}{*}{$\begin{array}{c}\text { Sunlight Exposure } \\
\text { duration (h.) }\end{array}$} & \multicolumn{2}{|c|}{ Larval Mortality(\%) } \\
\hline & & DpNPV* Suspension & $D p \mathrm{NPV}^{*}$ Formulation \\
\hline 1. & 1 & $\begin{array}{c}76.66 \\
(61.11)^{b}\end{array}$ & $\begin{array}{c}86.65 \\
(68.56)^{\mathrm{b}}\end{array}$ \\
\hline 2. & 2 & $\begin{array}{c}68.33 \\
(55.75)^{\mathrm{c}}\end{array}$ & $\begin{array}{c}78.33 \\
(62.25)^{\mathrm{c}}\end{array}$ \\
\hline 3. & 3 & $\begin{array}{c}68.33 \\
(55.75)^{\mathrm{c}}\end{array}$ & $\begin{array}{c}71.66 \\
(57.83)^{\mathrm{d}}\end{array}$ \\
\hline 4. & 4 & $\begin{array}{c}53.33 \\
(46.90)^{\mathrm{d}}\end{array}$ & $\begin{array}{c}65.00 \\
(53.72)^{\mathrm{e}}\end{array}$ \\
\hline 5. & 5 & $\begin{array}{c}48.33 \\
(44.04)^{\mathrm{e}}\end{array}$ & $\begin{array}{c}61.66 \\
(51.74)^{\mathrm{f}}\end{array}$ \\
\hline 6. & Control & $\begin{array}{c}90.00 \\
(71.56)^{\mathrm{a}}\end{array}$ & $\begin{array}{c}93.33 \\
(75.03)^{\mathrm{a}}\end{array}$ \\
\hline & SEd & 0.38 & 0.61 \\
\hline & CD at $(0.05 \%)$ & 0.82 & 1.33 \\
\hline
\end{tabular}

*DpNPV@ $1 \times 10^{9} \mathrm{POB} / \mathrm{ml}$

Values are mean of three replications

Values in parentheses are arc sine transformed values

Means followed by similar letter (s) are not significantly different by LSD

Table.2 Effect of UV light exposed DpNPV suspension and its formulation against larvae of $D$. pulverulentalis

\begin{tabular}{|c|c|c|c|}
\hline \multirow{2}{*}{ S.No } & \multirow{2}{*}{$\begin{array}{c}\text { UV Exposure duration } \\
\text { (min.) }\end{array}$} & \multicolumn{2}{|c|}{ Larval Mortality (\%) } \\
\hline & & $D p N P V *$ Suspension & $D p \mathrm{NPV}^{*}$ Formulation \\
\hline 1. & 5 & $\begin{array}{c}88.33 \\
(70.02)^{\mathrm{b}}\end{array}$ & $\begin{array}{c}93.33 \\
(75.03)^{\mathrm{b}}\end{array}$ \\
\hline 2. & 10 & $\begin{array}{c}85.00 \\
(67.21)^{\mathrm{c}}\end{array}$ & $\begin{array}{c}90.00 \\
(71.56)^{\mathrm{c}}\end{array}$ \\
\hline 3. & 15 & $\begin{array}{c}80.00 \\
(63.43)^{\mathrm{d}}\end{array}$ & $\begin{array}{c}86.65 \\
(68.56)^{\mathrm{d}}\end{array}$ \\
\hline 4. & 30 & $\begin{array}{c}66.66 \\
(54.73)^{\mathrm{e}}\end{array}$ & $\begin{array}{c}71.66 \\
(57.83)^{\mathrm{e}}\end{array}$ \\
\hline 5. & 60 & $\begin{array}{c}53.33 \\
(46.90)^{\mathrm{f}}\end{array}$ & $\begin{array}{c}66.66 \\
(54.73)^{\mathrm{f}}\end{array}$ \\
\hline 6. & Control & $\begin{array}{c}90.00 \\
(71.56)^{\mathrm{a}}\end{array}$ & $\begin{array}{c}95.00 \\
(77.07)^{\mathrm{a}}\end{array}$ \\
\hline & SEd & 0.45 & 0.39 \\
\hline & CD at $(0.05 \%)$ & 0.99 & 0.85 \\
\hline
\end{tabular}

*DpNPV@ $1 \times 10^{9} \mathrm{POB} / \mathrm{ml}$

Values are mean of three replications

Values in parentheses are arc sine transformed values

Means followed by similar letter (s) are not significantly different by LSD. 
Fig.1 Effect of sunlight exposed $D p N P V$ suspension and formulation against $D$. pulverulentalis

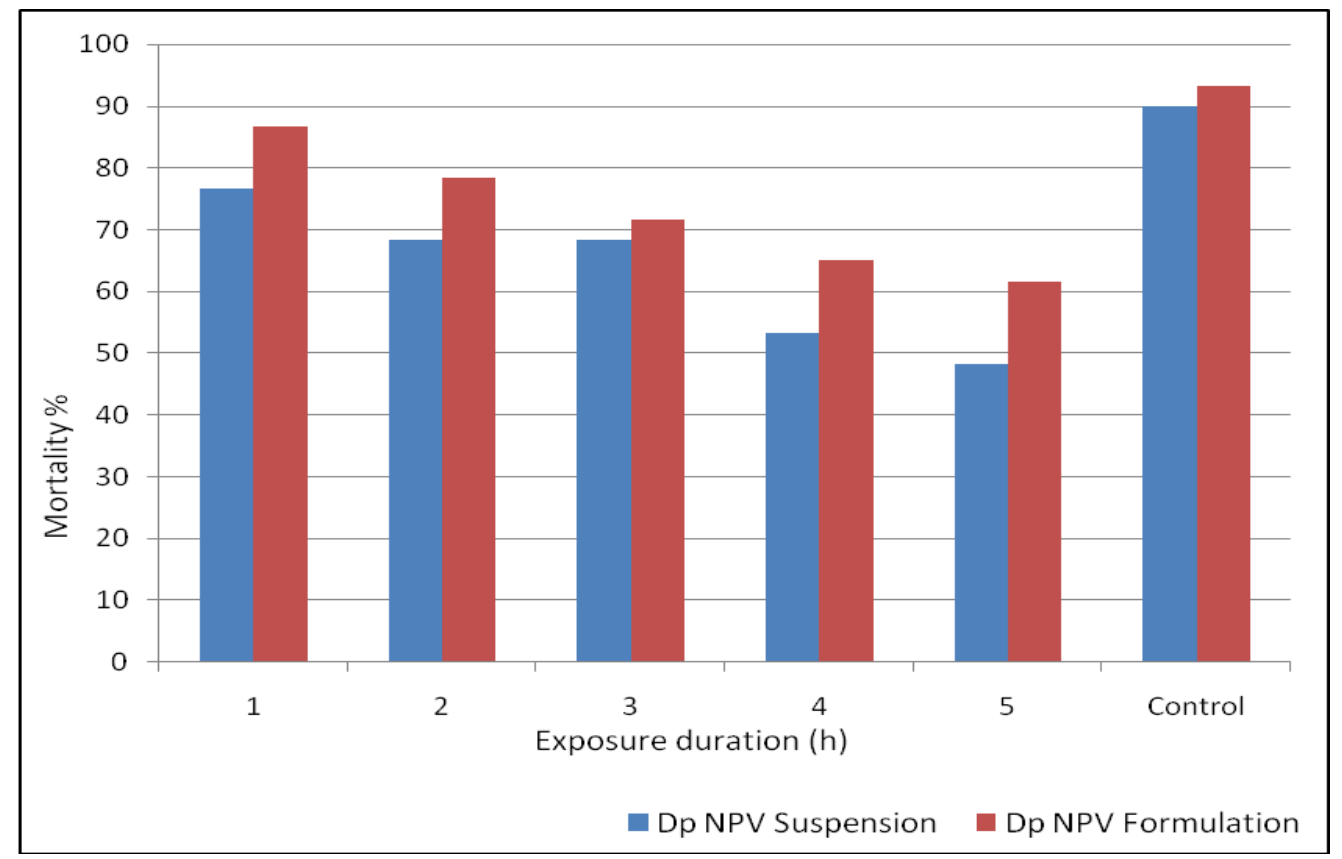

Fig.2 Effect of UVlight exposed $D p N P V$ suspension and formulation against $D$. pulverulentalis

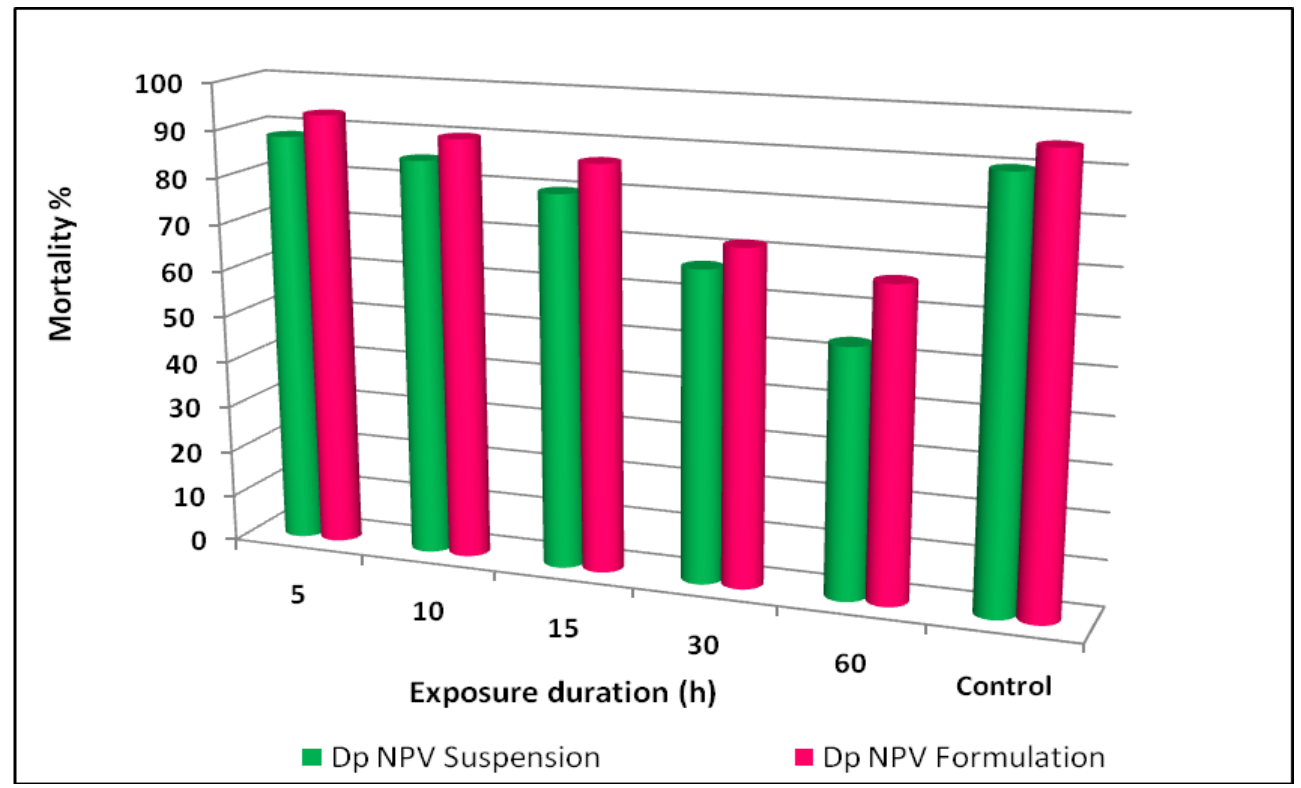

Effect of sunlight on the infectivity of NPV Hyphantria cunea determined in the laboratory and exposure of suspension of the virus to direct sunlight for $3 \mathrm{~h}$ resulted in 50 per cent reduction in the infectivity (Nordin,
1976). Also the effect of sunlight on the infectivity of NPV Mythimna seprata (Manjunath and Mathad, 1981; ParameshwarHugar et al., 1996); Trichoplusia ni (Biever and Hostetter, 1985) and Spodoptera litura 
(Kulkarni et al., 1999) has been were documented.

Effect of UVlight exposed $D p N P V$ and their formulations on the larval mortality of leaf webber, D. pulverulentalis

Survival might be achieved by persistence of polyhedra in soil or decaying leaf matter, particularly during periods when the insect host is not available (Hughes et al., 1997). Following application to plant surfaces, polyhedra are rapidly inactivated by solar ultraviolet (UV) radiation, particularly in the UV-B range of 280 320 nm (Killick, 1990; Morris, 1971).

Insect virues are known to be inactivated by artificial radiation (Watanabe, 1951; David, 1969; Bullock et al., 1970; Jaques, 1968). The purpose of the present study was directed towards obtaining basic information on the response of the nuclear polyhedrosis virus to $\mathrm{UV}$ radiation.

Significantly difference in larval mortality was observed when $D p N P V$ was exposed to 5, 10, 15, 30 and 60 minutes to UV light, (88.33, 85.00, 80.00, 66.66 and 53.33 per cent, respectively) (Fig. 2) However, virus without UV exposure caused mortality of 91.25 per cent which showed no significant loss in activity of $D p$ NPV (Priyadharshini, 2009). Shapiro et al., (2002) reported the effects of UV light on the activity of corn earworm, beet army worm and leaf webber nuclear polyhedrosis virus. Jones and Mckinnely (1986) demonstrated that $>90$ per cent inactivation of Spodoptera littoralis nuclear polyhedrosis (SIMNPV) occurred within 4 hours and more than $>99$ per cent inactivation occurred within 8 hours of exposure to UV light.

Several workers tested different adjuvants as UV protectants viz., carbon, aluminium powder, aluminium oxide and cellulose
(Ignoffo and Batzer, 1971), boric acid 0.1 to 1.0 per cent (Bijjur et al., 1993), Ranipal and Robin blue @ 0.5 per cent (Rabindra et al., 1989), Tinopal LPW (Ignoffo and Garcia, 1995), Ranipal BVN and Ranipal 2B (Murali baskaran et al., 1997). Whereas, in UV treated $D p N P V$ formulation showed the higher rate of larval mortality $(93.33,90.00,86.65,71.66$ and 66.66 per cent mortality in $5,10,15,30$ and 60 hour duration respectively). However, virus with no UV exposure caused mortality of 90.00 per cent in $D p N P V$ suspension and 95.00 per cent in $D p \mathrm{NPV}$ formulation, which showed no significant loss in activity. Hence, the inactivation of virus was directly related to the period of exposure to UV radiation. The viral activity of the irradiated suspensions decreased with increased exposure duration to UV light. The inactivation of virus was directly related to the period of exposure to $\mathrm{UV}$ radiation (Table 2 ).

Rabindra et al., (1989) reported that Robin blue and Tinopal when used as adjuvants increased the persistence of the virus on foliage and suggested that this could be attributed to the UV protection. Shapiro et al., (1983) evaluated different adjuvants and concluded that molasses, shade and coax served as UV protectants at 5 per cent concentration. Also, Stilbene derived optical brighteners could improve the insecticidal properties of baculoviruses (Lasa et al., 2007).

In conclusion, investigations were carried out on the Development and evaluation of formulation of $D p \mathrm{NPV}$ for the management of leaf webber Diaphania pulverulentalis (Hampson) in mulberry ecosystem. The results obtained from various laboratory experiments are concluded that, the larval mortality was significantly maximum (76.66 $\%$ ) when $D p$ NPV suspension was exposed to sunlight for $1 \mathrm{hr}$, which was followed by mortality of $68.33,68.33,53.33$ and 48.33 per cent for 2, 3, 4 and $5 \mathrm{hr}$ respectively. Whereas, 
comparatively formulated $\mathrm{DpNPV}$ (Starch 10\%+ Tinopal 0.2\%+ Tween $80(1 \%)+D p N P V @$ $1 \times 10^{9}$ POBs $\mathrm{ml}^{-1}$ ) showed significantly maximum larval mortality $(86.65 \%)$ when exposed to sunlight for $1 \mathrm{hr}$, than $D p N P V$ alone, which was followed by mortality of 78.33, 71.66, 65.00 and 61.66 per cent for 2, 3, 4 and $5 \mathrm{hr}$ respectively, indicating inverse relationship between the exposure duration to sunlight and larval mortality.

Significant difference in larval mortality was observed when $D p$ NPV was exposed to 5,10 , 15,30 and 60 minutes to UV light, (88.33, $85.00,80.00,66.66$ and $53.33 \%$ mortality, respectively. Whereas, in formulated $D p N P V$, the rate of larval mortality recorded was higher (93.33, 90.00, 86.65, 71.66 and 66.66 $\%$ respectively). The inactivation of virus was directly related to the period of exposure to UV radiation.

\section{Acknowledgement}

The senior author sincerely acknowledges the Rajiv Gandhi National Fellowship (RGNF) for the financial support in the form of Senior research fellowship for his Ph.D. research. Thanks are also due to the Head and Chairman for providing field and laboratory facilities at the Department of Sericulture, Tamil Nadu Agricultural University, during the course of this investigation.

\section{References}

Biever, K.D. and D.L. Hostteter. 1985. Field persistence of Trichoplusia ni (Lepidoptera: Noctuidae) singleembedded nuclear polyhedrosis virus on cabbage foliage. Environ. Entomol., 14(5): 579-581.

Bijjur, S., K.A. Kulkarni and S. Lingappa. 1993. Evaluation of nuclear polyhedrosis virus with certain adjuvants for the control of Helicoverpa armigera (Hubner). Karnataka J. Agric. Sci., 6: 259-262.

Broome, J.R., P.P. Sikorowski, and W.W. Neel. 1974. Effect of sunlight on the activity of nuclear polyhedrosis virus from Malacosoma disstria. J. Econ. Entomol., 67(1): 135-136.

Bullock, H. R., J. P. Hollingsworth and A. W. Hartstack. 1970. Virulence of Heliothis nuclear polyhedrosis virus exposed by monochromatic ultraviolet irradiation. J. Invertebr. Pathol., 16: 419-422.

David, W.A.L. 1969. The effect of ultraviolet radiation of known wavelengths on a granulosis virus of Pieris brassicae. $J$. Invertebr. Pathol., 14: 336-342.

Dent, D. and N.E. Jenkins. 2000. Microbial pesticides in augmentative control. In augmentative biocontrol: proceedings of the ICAR-CABI workshop (S P Singh, S $\mathrm{T}$ Murphy and $\mathrm{C} \mathrm{R}$ Ballal Eds.) Bangalore, Karnataka, India.

Geethabai, M., B. Marimadaiah, K.C. Narayanaswamy and D. Rajagopal. 1997. An outbreak of leaf roller pest, Diaphania (=margaronia) pulverulentalis (Hampson) on mulberry in Karnataka. Geobios New Reports, 16(2):73-79.

Hughes, P.R., H.A. Wood, J.P. Breen, S.F. Simpson, A. J. Duggan and J. A. Dybas. 1997. Enhanced bioactivity of recombinant baculoviruses expressing insect-specific spider toxins in lepidopteran crop pests. J. Invertebr. Pathol., 69: 112-118.

Ignoffo, C.M. and C. Garcia. 1995. Aromatic/Heterocyclic amino acids and the stimulated sunlight ultraviolet inactivation of the Heliothis/ Helicoverpa Baculovirus. Environ. Ent., 24: 480-482.

Ignoffo, C.M. and O.P. Batzer. 1971. Microencapsulation and ultraviolet protectants to increase sunlight stability of an insect virus. J. Econ. Ent., 64: 
8531860.

Ignoffo, C.M., W.C. Rice and A.H. Mcintosh. 1989. Inactivation of non occluded and occluded baculoviruses and baculovirus DNA exposed to simulated sunlight. Environ. Entomol., 18(1): 177-183.

Jaques. R.P. 1968. The inactivation of the nuclear polyhedrosis virus of Trichloplusia ni by gamma and ultraviolet radiation. Can. J. Microbiol., 14: 1161-1163.

Jones, K.A. and D.J. Mckinely. 1986. UV inactivation of Spodoptera litura nuclear polyhedrosis virus in Egypt: assessment and protection. In "Fundamentals and applied aspects of Invertebrate pathology" (eds. Samson, R. A., Vlak, J. M. and Peters, D),Proceedings IV International Colloquium on invertebrate pathology, wageningen, Netherlands, p155.

Killick, H.J. 1990. Influence of droplet size, solar ultraviolet light and protectants, and other factors on the efficacy of baculovirus sprays against Panolis flammea (Schiff.) (Lepidoptera: Noctuidae). Crop Prot, 9: 21-28.

Kulkarni, C.G., S.S.R. Kumar, S. P. Hugar and K. A. Kulkarni. 1999. Persistance of NPV against Spodoptera litura Fab.On strawberry in transitional tract of Karnataka. Ann. Agric. Bio. Res, 4(1): 45-47.

Lasa, R., C. Ruiz-Portero, M.D. Alcazar, J. E. Belda, P. Caballero and T. Williams. 2007. Efficacy of optical brightener formulations of Spodoptera exigua multiple nucleopolyhedrosis ( $\mathrm{SeMNPV}$ ) as a biological insecticide in green houses in Southern Spain. Biol. Control, 40: 89-96.

Manjunath, D. and S. B. Mathad. 1981. Effect of sunlight on the infectivity of purified and non-purified virus NPV of the armyworm, Mythimna separate Waller. Ind. J. Sci, 51: 750-756.
McLeod, P.J., W.C. Yearian and S.Y. Young. 1977. Inactivation of Baculovirus heliothis by ultraviolet irradiation, dew and temperature. J. Invertebr. Pathol, 30: $237-241$.

Morris, O.N. 1971. The effect of sunlight, ultraviolet, gamma radiations and temperature on infectivity of a nulearpolyhedrosis virus. J. Invertebr. Pathol., 18: 292-294.

Muralibaskaran, M.S., M. S. Venugopal and N.R. Mahadevan. 1997. Optical brighteners as UV protectants and their influence on the virulence of nuclear polyhedrosis virus of Spodoptera litura (Fab.) (Lepidoptera: Noctuidae). J. Biol. Control, 11: 17-22.

Narayanaswamy, K.C., B.R. Mamatha Gowda and P. Priyadharshini. 2008. Cross infectivity of pathogens of leaf roller, Diaphania pulverulentalis (Hampson) to Bombyx mori L. and. its influence on some economic traits. Dr. Leslie $C$. Coleman Memorial National Symposium on Plant Protection, $4-6^{\text {th }}$ December, UAS, GKVK, Bangalore.pp. 1- 3.

Nordin, G.L. 1976. Transovum transmission of a nuclear polyhedrosis virus of the fall webworm, Hyphantria cunea (Lepidoptera: Arctiidae). J. Kansas Entomol. Soc., 49(4): 589-594.

Parameshwar - Hugar, K., A. Kulkarni and S. Lingappa. 1996. Persistance of NPV of Mythimna separata (Walker) on sorghum foliage. Karnataka J. Agric. Sci., 9(1): 51-55.

Priyadharshini, P. 2009. Molecular characterization of NPV of Diaphania pulverulentalis (Hampson) and establishment of phylogenetic relationship with other lepidoptera and baculoviruses. Ph.D Thesis, University of Agricultural Sciences, Banglore, $\mathrm{p}$ 88.

Rabindra, R.J. and S. Jayaraj. 2005. Effect of 
nuclear polyhedrosis infection on the insecticide susceptibility on Helicoverpa armigera and Spodoptera litura larvae. J. Biol. Control, 4: 31-34. Rabindra, R. J., N. Sathiah, C. Muthiah and S. Jayaraj. 1989. Controlled droplet application of nuclear polyhedrosis virus with adjuvants and UV protectants for the control of Heliothis armigera (Hbn) on chickpea. J.Biol. Control, 3: 37- 39.

Sajap, A. S., M. A. Bakir, H. A. Kadir and N. A. Samad. 2007. Effect of $\mathrm{pH}$, rearing temperature and sunlight on infectivity of Malaysian isolate of nucleopolyhedrovirus to larvae of Spodoptera litura (Lepidoptera: Noctuidae). Int. J Trop. Insect Sci, 27: 108-113.

Sajap, A. S., M. A. Bakir, H. A. Kadir and N. A. Samad. 2009. Efficacy of selected adjuvants for protecting Spodoptera litura nucleopolyhedrovirus from sunlight inactivation. J. Asia-Pacific Entomol, 12: 85-88.

Shapiro, M., P. P. Agnin and R. A. Bell. 1983. Ultraviolet protectants of the gypsy moth (Lepidoptera: Lymantriidae) nucleopolyhedrosis virus. Environ. Entomol, 12: 982-985.

Shapiro, M., R. Robert, J. R. Farrar, J. Domek and I. Javaid. 2002. Effects of virus concentrations and ultraviolet irradiation on the activity of corn earworm and beet armyworm (Lepidoptera: Noctuidae) nucleopolyhedroviruses. J. Econ. Entomol, 95(2): 243-249.

Watanabe, S., 1951, Studies on the grasserie virus of the silkworm, Bombyx mori. IV. Physical and chemical effects upon the virus. Jpn. J. Exp. Med, 21: 229313.

\section{How to cite this article:}

Prabhu, S. and Mahalingam, C.A. 2017. Effect of Sunlight and UV Light against DpNPV (Nuclear Polyhedrosis Virus) Formulation on Larval Mortality of Mulberry Leaf Webber, Diaphania pulverulentalis Hampson. Int.J.Curr.Microbiol.App.Sci. 6(3): 1897-1905. doi: https://doi.org/10.20546/ijcmas.2017.603.215 